\title{
THE EFFECT OF NUTRITION AND SEVERITY OF IRON DEFICIENCY ANAEMIA ON GROWTH IN CHILDREN FROM TWO MONTHS TO TWO YEARS OF AGE
}

\author{
T. Petkova-Marinova ${ }^{1^{*}}$, V. Nedkova ${ }^{2}$ \\ ${ }^{1}$ Department of Physiology, Medical University, Pleven, Bulgaria \\ ${ }^{2}$ Department of Pediatrics, Medical University, Pleven, Bulgaria
}

\begin{abstract}
Iron deficiency anaemia (IDA) is associated with increased morbidity, mortality, impaired growth and cognitive development of children. PURPOSE: to evaluate the effect of nutrition and severity of IDA on growth in children from 2 to 24 months of age. METHODS 172 children aged 2-24 months with IDA were categorized into two groups: G1 (0-12 months) and G2 (13-24 months). Diet was studied through interview. Anthropometric parameters: height-for-age (HA) and weight-for-age were assessed by standardized methods. IDA was defined as haemoglobin $(\mathrm{Hb})$, mean corpuscular volume, serum iron, and transferrin saturation below age-related reference values of the World Health Organization. Anaemia was classified as severe, moderate, and mild according to $\mathrm{Hb}$ concentration. Associations between variables were analyzed by logistic regression. RESULTS High proportions of children predominantly fed on cow's milk with scarce or absent intake of meat, eggs, vegetables were found in G1 (30.2\%) and G2 (19.8\%). Predominant cow's milk feeding was significantly associated with growth retardation $(\mathrm{HA}<3 \mathrm{rd}$ percentile). In $\mathrm{G} 2$, severe anemia $(\mathrm{Hb}<70 \mathrm{~g} / \mathrm{l})$ exhibited significant $(\mathrm{p}=0.0344)$ association with stunting. CONCLUSIONS Inadequate nutrition and severe IDA increase risk of growth retardation in the first two years of life. Promotion of appropriate feeding practices is important in prevention and control of IDA.
\end{abstract}

Key words: anaemia, anthropometry, child, cow's milk feeding, height-for-age, iron deficiency, weightfor-age

\section{INTRODUCTION}

Iron deficiency anaemia (IDA) impairs physical growth, cognitive performance, and resistance to infections leading to increased morbidity and mortality rates $(1,2)$. The population group which is most affected are infants and children less than 2 years of age. Intensive growth in the first two years of life includes a significant increase in erythrocyte and tissue volume and requires a high intake of iron which is frequently not provided by the diet. Anemia in this age group is considered a major global public health problem because of its highest frequency $(3,4)$. According to World Health Organization (WHO) estimates, global prevalence of anaemia among children from 0 to 5 years of age averages $47.4 \%$ (5). National survey in Bulgaria has determined anaemia prevalence among children from 6

\footnotetext{
*Correspondence to: Tsvetelina PetkovaMarinova,: 1 St. Kliment Ohridski Str., 5800 Pleven, Bulgaria, Telephone number: +359896623 219; +359 64884218, E-mail: cveti_doc@abv.bg
}

months to 5 years of age $31.1 \%$ which is categorized by the WHO as a public health problem of moderate significance (6).

It is known the negative impact of IDA on the physical growth of infants and children. A number of studies have found significant relationships of anaemia with lower growth and developmental indicators in children of different ages $(6,7,8)$. The exact mechanism by which IDA impairs growth has not been elucidated yet. Many mechanisms have been proposed, such as adverse effects of iron deficiency on DNA synthesis, cell cycle, and cell proliferation, immunity, appetite, production and metabolism of thyroid hormones, thermogenesis $(1,9,10)$. Moreover, contradictory evidence has been gathered regarding the effect of iron supplementation on physical growth. Numerous studies have clearly found improved growth by iron supplementation in anaemic children (11-14). However, a systematic review of randomised controlled trials did not determine a positive 
effect of iron supplementation on the physical growth of children (9). The question on factors affecting physical growth of children with IDA still remains open and needs further investigation.

Inadequate dietary intake of iron is the main cause of IDA in infancy and early childhood (2). Nutrition is the key factor for normal erythropoiesis and normal growth. Severe anaemia is a major risk factor for increased morbidity and mortality in infants and children (1).

The aim of study is to evaluate the effect of nutrition and severity of IDA on growth in children from 2 to 24 months of age.

\section{MATERIALS AND METHODS}

172 children aged from 2 to 24 months with IDA were examined. The study population was categorized into two age groups: G1 (0-12 months; $\mathrm{n}=86$ ) and G2 (13-24 months; $\mathrm{n}=86$ ).

Diet was studied through interview assessing current milk feeding practice (breastfeeding, formula and/or cow's milk feeding), daily frequency of milk intake for non-breastfed children, weekly intake frequency of complementary foods: meat, eggs, and vegetables.

Anthropometric measurements were performed by standardized procedures. Length/height was measured to the nearest $0.1 \mathrm{~cm}$ using a standard child measuring board or a standard stadiometer. Weight was determined to the nearest $0.1 \mathrm{~kg}$ with a calibrated pediatric scale. Individual anthropometric parameters: heightfor-age (HA) and weight-for-age (WA) were assessed by the method of percentiles according to reference data of the WHO for the respective age and gender (15). HA $<3^{\text {rd }}$ percentile was used to categorize low heightfor-age denoted as growth retardation or
PETKOVA-MARINOVA T., et al. stunting, and WA $<3^{\text {rd }}$ percentile was defined as low weight-for-age or underweight.

IDA was defined as haemoglobin $(\mathrm{Hb})$ values less than $110 \mathrm{~g} / \mathrm{l}$, and presence of the following parameters: mean corpuscular volume (MCV) below the respective age-related reference values of the $\mathrm{WHO}$, serum iron $(\mathrm{SFe})<8.95$ $\mu \mathrm{mol} / 1$, and transferrin saturation (SatTf) $<16 \%$ $(1,16)$. Percent SatTf was calculated as a ratio of $\mathrm{SFe}$ and total iron-binding capacity. Haematological parameters and biochemical markers of iron metabolism were determined by standard clinical laboratory methods. Anaemia was classified as severe $(\mathrm{Hb}<70 \mathrm{~g} / \mathrm{l})$, moderate (Hb 70-99 g/l), and mild (Hb 100-110 $\mathrm{g} / \mathrm{l})$.

Crude relations of growth with nutrition, severity of anemia, and other factors were tested by Pearson's $\chi^{2}$-test. Logistic regression was used to obtain adjusted odds ratios (ORs) and $95 \%$ confidence intervals (95\% CIs) for analyzing associations between variables. The potential effects of outliers were evaluated in all analyses. Statistical significance was indicated by $\mathrm{p}<0.05$.

\section{RESULTS}

Assessment of anthropometric indicators height-for-age and weight-for-age established relatively high proportions of children with growth retardation and underweight among children with IDA in both age groups (Figure 1). Low height-for-age was identified in $25.6 \%$ $(n=22)$ of infants in $\mathrm{G} 1$ and $24.4 \%(n=21)$ of children in G2. Low weight-for-age was detected in $15.1 \%(n=13)$ of $\mathrm{G} 1$ and $12.8 \%$ $(n=11)$ of $G 2$. There were no significant differences with respect to the relative frequencies of growth retardation and underweight between the two age groups $\left(\chi^{2}-\right.$ test, $\mathrm{p} \geq 0.05$ ).

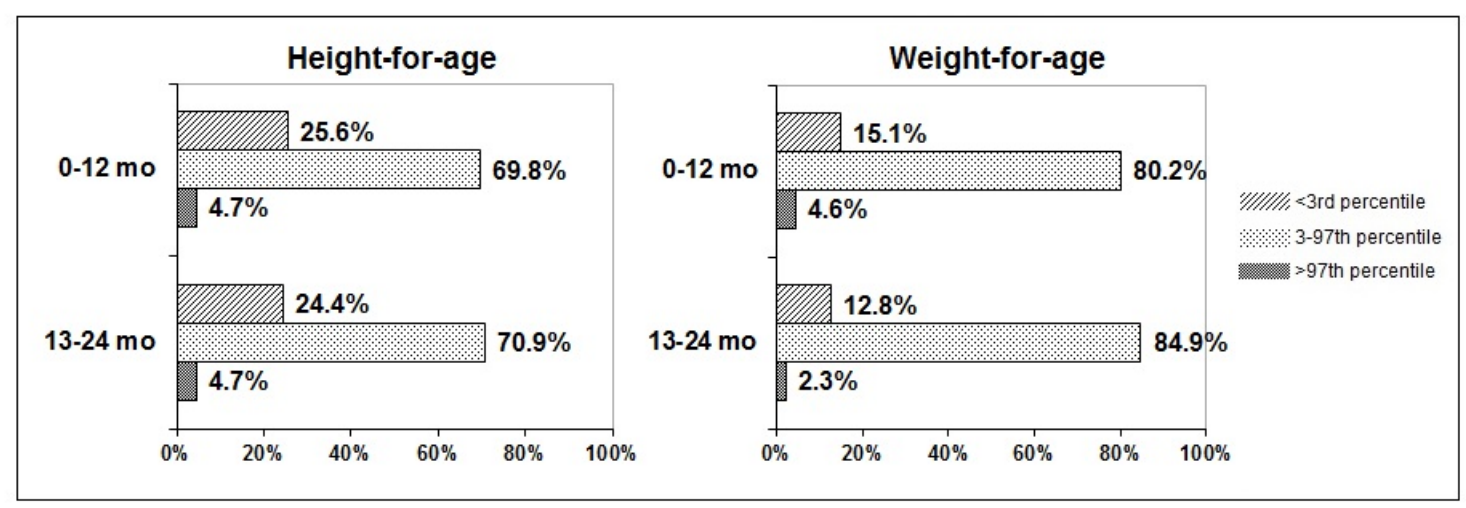

Figure 1. Distribution of the study groups by the anthropometric indicators height-for-age and weight-for-age according to the method of percentiles. 
Assessment of nutrition showed that among investigated children with IDA, the most frequent type of milk feeding during the study time was cow's milk. In the 0-12 months group, $19.8 \%(\mathrm{n}=17)$ of infants were breastfed, $70.9 \%(\mathrm{n}=61)$ were fed on cow's milk, and $9.3 \%(n=8)$ were formula fed. At the age 13-24 months, milk feeding was human milk for $18.6 \%(\mathrm{n}=16)$ of children, cow's milk for $80.2 \%(n=69)$, and formula for $1.2 \%(n=1)$. Evaluation of intake frequency of complementary foods for the children over 6 months of age revealed that in G1, 91.8\% $(n=67)$ of infants never or rarely (less than 1 time per week) consumed meat and eggs. In the 13-24 months group, $82.6 \% \quad(n=71)$ of children never or rarely consumed meat, and
$86.1 \%(\mathrm{n}=74)$ never had eggs. Assessment of nutrition showed high proportions of children predominantly fed on cow's milk with scarce or absent intake of complementary foods: meat, eggs, and vegetables in both age groups: G1 (30.2\%; $n=26)$ and G2 (19.8\%; $n=17)$.

Distribution of the study groups according to $\mathrm{Hb}$ concentration showed a tendency for more severe anaemia among the children of higher age (Figure 2). In G1, relative rate of severe anaemia was $14.0 \%(\mathrm{n}=12)$, and in $\mathrm{G} 2,24.4 \%$ $(n=21)$ of children were severely anaemic. No significant difference in the relative rates of severe anemia between the two age groups was found $\left(\chi^{2}\right.$-test, $\left.p \geq 0.05\right)$.

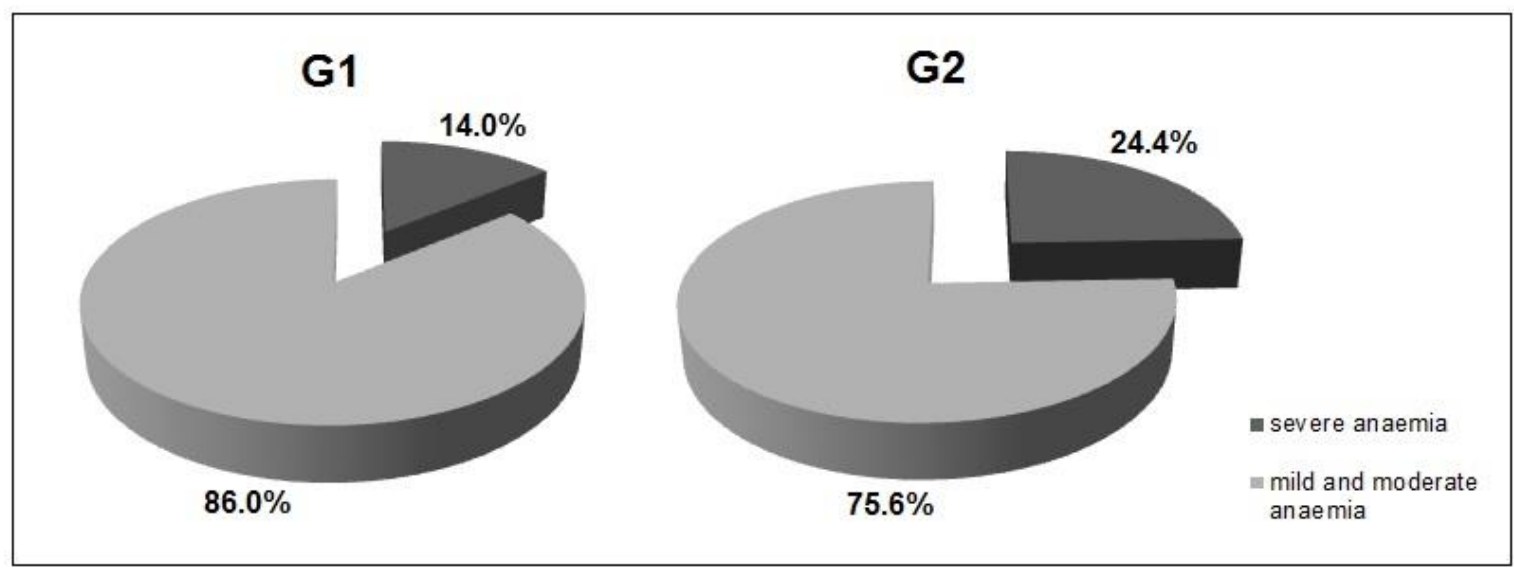

Figure 2. Relative frequencies of severe anaemia among children with IDA in age groups G1 and G2.

In order to determine potential factors influencing growth in the study population, we used comparisons with respect to child gender, birth weight, current feeding practice, and severity of IDA between anaemic children with low height-for-age and weight-for-age and anaemic children without growth retardation and underweight.

In both G1 and G2, relative frequency of predominant cow's milk feeding was significantly higher $\left(\chi^{2}\right.$-test, $\left.\mathrm{p}<0.05\right)$ among children with $\mathrm{HA}<3^{\text {rd }}$ percentile than children without growth retardation (Table 1). At age 13-24 months, children with low height-forage had significantly higher relative rates of severe IDA than children without growth retardation $\left(\chi^{2}\right.$-test, $\left.\mathrm{p}=0.004\right)$. No significant differences with respect to infant gender and low birth weight $(<2500 \mathrm{~g})$ were detected between children with stunting and children without growth retardation $(\mathrm{p} \geq 0.05)$.

Table 1. Characteristics of anaemic children with stunting and anaemic children without growth retardation with respect to child gender, birth weight, current feeding practice, and severity of IDA ${ }^{l}$

\begin{tabular}{lllll}
\hline \multirow{2}{*}{ Indicator variable } & \multicolumn{3}{c}{ G1 } & G2 \\
\cline { 2 - 5 } & $\begin{array}{l}\text { Children with } \\
\text { stunting }\end{array}$ & $\begin{array}{l}\text { Children without } \\
\text { stunting }\end{array}$ & $\begin{array}{l}\text { Children with } \\
\text { stunting }\end{array}$ & $\begin{array}{l}\text { Children without } \\
\text { stunting }\end{array}$ \\
\hline Gender (female) & $40.9 \%(9)$ & $28.1 \%(18)$ & $42.9 \%(9)$ & $49.2 \%(32)$ \\
\hline Birth weight <2500 g & $45.5 \%(10)$ & $28.1 \%(18)$ & $47.6 \%(10)$ & $26.2 \%(17)$ \\
\hline $\begin{array}{l}\text { Predominant cow's } \\
\text { milk feeding }\end{array}$ & $59.1 \%(13)$ & $20.3 \%(13)^{*}$ & $42.9 \%(9)$ & $12.3 \%(8)^{*}$ \\
\hline Severe anemia & $9.1 \%(2)$ & $15.6 \%(10)$ & $47.6 \%(10)$ & $16.9 \%(11)^{*}$ \\
\hline \multicolumn{2}{l}{ "Values are presented as \% (n). } \\
"Different from children with stunting $\left(\chi^{2}\right.$-test), $<<0.05$. & &
\end{tabular}


Anaemic children with low weight-for-age and anaemic children without underweight did not differ significantly with respect to child gender, birth weight, current feeding practice, and severity of IDA (Table 2).

Table 2. Characteristics of anaemic children with underweight and anaemic children without underweight with respect to child gender, birth weight, current feeding practice, and severity of IDA ${ }^{1}$

\begin{tabular}{lllll}
\hline \multirow{2}{*}{ Indicator variable } & \multicolumn{3}{c}{ G1 } & G2 \\
\cline { 2 - 5 } & $\begin{array}{l}\text { Children with } \\
\text { underweight }\end{array}$ & $\begin{array}{l}\text { Children without } \\
\text { underweight }\end{array}$ & $\begin{array}{l}\text { Children with } \\
\text { underweight }\end{array}$ & $\begin{array}{l}\text { Children without } \\
\text { underweight }\end{array}$ \\
\hline Gender (female) & $38.5 \%(5)$ & $30.1 \%(22)$ & $45.5 \%(5)$ & $48.0 \%(36)$ \\
\hline Birth weight $<2500 \mathrm{~g}$ & $46.2 \%(6)$ & $30.1 \%(22)$ & $72.7 \%(8)$ & $25.3 \%(19)$ \\
\hline $\begin{array}{l}\text { Predominant cow's } \\
\text { milk feeding }\end{array}$ & $61.5 \%(8)$ & $24.7 \%(18)$ & $90.9 \%(10)$ & $9.3 \%(7)$ \\
\hline Severe anemia & $15.4 \%(2)$ & $13.7 \%(10)$ & $36.4 \%(4)$ & $22.7 \%(17)$ \\
\hline \multicolumn{1}{|l}{ Values are presented as \% (n). } & & &
\end{tabular}

Logistic regression analysis showed that in both age groups, predominant cow's milk feeding was significantly associated with increased risk of growth retardation (Table 3). In G1, infants predominantly fed on cow's milk were nearly 6 times more likely to be stunted than those who were breastfed, formula fed, or had been introduced to complementary foods (OR: 5.65; 95\% CI: 1.8-17.74; $\mathrm{p}=0.002$ ). At age 13-24 months, children predominantly fed on cow's milk had a 4-fold increased odds of being stunted compared to children introduced to complementary foods (OR: 4.06; 95\% CI: 1.16-14.19; $\mathrm{p}=0.026)$. Regression model indicated that at age 13-24 month, severe anemia contributed to a 3.5-fold increased risk of stunting compared with anaemia of less degree (OR: 3.47; 95\% CI: 1.08-11.08; $\mathrm{p}=0.034$ ). Birth weight and infant gender were not significant factors in the model applied.

Table 3. Individual variables and their adjusted odds ratios (95\% confidence interval) for growth retardation ( $H A<3{ }^{\text {rd }}$ percentile) of children with IDA by logistic regression analysis

\begin{tabular}{lllllll}
\hline \multicolumn{1}{c}{ Indicator variable } & \multicolumn{3}{c}{ G1 } & \multicolumn{3}{c}{ G2 } \\
\cline { 2 - 7 } & OR & $95 \%$ CI & p-value & OR & $95 \%$ CI & p-value \\
\hline Gender (female) & 1.3 & $0.4-4.21$ & 0.659 & 0.85 & $0.26-2.77$ & 0.785 \\
\hline Birth weight <2500 g & 1.21 & $0.37-3.97$ & 0.749 & 1.93 & $0.59-6.27$ & 0.271 \\
\hline $\begin{array}{l}\text { Predominant cow's milk } \\
\text { feeding }\end{array}$ & 5.65 & $1.8-17.74$ & $0.002^{*}$ & 4.06 & $1.16-14.19$ & $0.026^{*}$ \\
\hline Severe anemia & 0.36 & $0.06-2.12$ & 0.222 & 3.47 & $1.08-11.08$ & $0.034^{*}$ \\
\hline \multicolumn{1}{l}{ Statistical significance is indicated by *. }
\end{tabular}

\section{DISCUSSION}

In this study population of children with IDA, we found relatively high rates of growth retardation and underweight in both age groups. It is known that anthropometric indicators are measures of the individual's nutritional status reflecting adequacy of energy and nutrient intake. Therefore, undernutrition was prevalent among the study population. As shown by our results, predominant feeding on cow's milk with scarce or absent intake of complementary foods in investigated food groups (meat, eggs, vegetables) was a common feeding practice among infants and children with IDA. Observed association between predominant cow's milk feeding and low children's height-for-age was not unexpected, because, as stated by the WHO, low height-for age is an indicator of chronic undernutrition (17). Low intakes of energy, protein, and micronutrients provided by the incorrect feeding practice can all contribute to impaired child growth. Moreover, inadequate nutrition may also deteriorate growth indirectly by its adverse effects on the immunity leading to more frequent and long lasting infections which diminish growth rate $(18,19)$. However, this study does not provide an assessment of incidence of infectious disease among investigated children with IDA.

As stated by the WHO and Centers for Disease Control and Prevention, early introduction of cow's milk and predominant feeding on cow's milk are considered important risk factors for iron deficiency in infants and young children $(17,20)$. Use of cow's milk as a main weaning food may lead to iron deficiency by two possible mechanisms (21). Cow's milk contains low amounts of iron and interferes 
PETKOVA-MARINOVA T., et al.

with iron absorption due to its high concentrations of calcium, phosphorus, protein, and low concentration of ascorbic acid $(22,23)$. Secondly, introduction of cow's milk before the age of 1 year may induce significant loss of iron through chronic, occult intestinal bleeding due to cow's milk protein intolerance (23). There is substantial scientific evidence that deficiency of iron exerts a negative impact on growth by different mechanisms, some of which not completely investigated, e.g., effects on the cell cycle, cell proliferation, immunity, appetite, thyroid function, thermogenesis $(1,9$, 10). Detrimental effects of iron deficiency on physical growth might account for the observed association between predominant cow's milk feeding and growth retardation in the study population of children with IDA.

Our results showed a greater relative rate of severe anaemia among the children between 13 and 24 months of age compared to the lower age group. We consider that this was probably due to the fact that among the period of infancy and early childhood, second year of life presents the greatest prevalence of iron deficiency and IDA (1). Respectively, an association between severe anemia and growth retardation was found in the group of children aged 13-24 months, but not at the lower age.

In our study, we did not find a significant relation between low birth weight and stunting in either of age groups although the WHO indicates that premature birth and intrauterine growth retardation are important causes of delayed growth during the first years of life (17).

\section{CONCLUSIONS}

Our data showed that inadequate nutrition and severe IDA increased risk of growth retardation in the first two years of life. Observed relationship between predominant cow's milk feeding and low children's heightfor-age highlights the importance of appropriate nutrition for physical growth and development in the first two years of life. Low birth weight was not a significant risk factor for stunting in investigated population of children with IDA. Further research is needed to fully understand the factors causing growth impairments in infants and children with IDA. Promotion of appropriate feeding practices and adequate complementary foods is important in prevention and control of IDA and its consequences on physical growth.

\section{REFERENCES}

1. World Health Organization, Iron Deficiency Anemia: Assessment, Prevention, and Control - a Guide for
Program Managers. World Health Organization, Geneva, Switzerland, 2001. WHO/NHD/01.3.

2. Kotecha, PV., Nutritional anemia in young children with focus on Asia and India. Indian J Community Med, 36(1):8-16, 2011.

3. Queiroz, SS. and Torres, MAA., Iron deficiency anemia in children. $J$ pediatr (Rio J.), 76(Suppl 3):S298-304, 2000.

4. McLean, E., Egli, I., Cogswell, M., Benoist, B., and Wojdyla, D., Worldwide prevalence of anemia in preschool aged children, pregnant women and non-pregnant women of reproductive age. In: Kraemer K, Zimmermann MB (eds), Nutritional Anemia. Sight and Life Press, Basel, Switzerland, pp 1-12, 2007.

5. Benoist, B., McLean, E., Egli, I., and Cogswell, M., eds, Worldwide Prevalence of Anaemia 1993-2005. World Health Organization, Geneva, Switzerland, 2008.

6. Petrova, S., Ovcharova, D., Rangelova, L., Duleva, V., Angelova, K., Kalinov, K., Dimitrov, P., Bojilova, D., Baikova, D., Vatralova, K., Popivanova, A., Marinova, M., Antonova, C., and Duneva, Z., National survey on nutrition of infants and children under 5 years of age and family child rearing in Bulgaria. Report. Transl. The National Center of Public Health Protection, 2009.

7. Tatala, S., Svanberg, U., and Mduma, B., Low dietary iron availability is a major cause of anemia: a nutrition survey in the Lindi District of Tanzania. Am J Clin Nutr, 68:171-8, 1998.

8. Zhao, A., Zhang, Y., Peng, Y., Li, J., Yang, T., Liu, Z., Lv, Y., and Wang, P., Prevalence of anemia and its risk factors among children 6-36 months old in Burma. Am J Trop Med Hyg, 87(2):306-311, 2012.

9. Sachdev, H., Gera, T., and Nestel, P., Effect of iron supplementation on physical growth in children: systematic review of randomised controlled trials. Public Health Nutr, 9(7):904-20, 2006.

10.Sangani, RG., and Ghio, AJ., Iron, human growth, and the global epidemic of obesity. Nutrients, 5:4231-4249, 2013.

11.Latham, MC., Stephenson, LS., Kinoti, SN., Zaman, MS., Kurz, KM., Improvements in growth following iron supplementation in young Kenyan school children. Nutrition, 6(2):159-65, 1990.

12.Angeles, IT., Schultink, WJ., Matulessi, P., Gross, R., and Sastroamidjojo, S., Decreased rate of stunting among anemic Indonesian preschool children through iron supplementation. Am J Clin Nutr, 58:33942, 1993. 
13.Bandhu, R., Shankar, N., and Tandon, OP., Effect of iron on growth in iron deficient anemic school going children. Indian $J$ Physiol Pharmacol, 47:59-66, 2003.

14.Stoltzfus, RJ., Heidkamp, R., Kenkel, D., and Habicht, JP., Iron supplementation of young children: Learning from the new evidence. Food Nutr Bull, 28:S572-S584, 2007.

15.WHO Multicentre Growth Reference Study Group, WHO Child Growth Standards: Length/height-for-age, weight-for-age, weight-for-length, weight-for-height and body mass index-for-age: Methods and development. World Health Organization, Geneva, 2006.

16. World Health Organization and Centers for Disease Control and Prevention, Assessing the iron status of populations. 2nd ed., World Health Organization, Geneva, Switzerland, 2007.

17.World Health Organization, Regional Publications, European Series, № 87, Feeding and nutrition of infants and young children. World Health Organization,
PETKOVA-MARINOVA T., et al.

WHO Regional Office for Europe, Denmark, Copenhagen, 2003.

18. Stephensen, CB., Burden of infection on growth failure. J Nutr, 129:534S-538S, 1999.

19.Saeidi, M., Vakili, R., Khakshour, A., Moghaddam, HT., Zarif, B., Nateghi, S., and Kiani, MA., Iron and multivitamin supplements in children and its association with growth rate. International Journal of Pediatrics, 1(1):13-7, 2013.

20.Centers for Disease Control and Prevention, Recommendations to prevent and control iron deficiency in the United States. MMWR Recomm Rep, 47:1-29, 1998.

21.Konstantinov, D., Clinical and laboratory characteristics of the most popular anaemic states in childhood. Transl. Journal Pediatria, XL(2):68-74, 2000.

22. Oski FA., Iron deficiency in infancy and childhood. The New England Journal of Medicine, 329(3):190-3, 1993.

23.Wu, AC., Lesperance, L., and Bernstein, H., Screening for iron deficiency. Pediatrics in Review, 23(5), 2002. 